Sains Malaysiana 47(3)(2018): 619-633

http://dx.doi.org/10.17576/jsm-2018-4703-24

\title{
Peranti Suis Nanoelektromekanikal (NEM) Berunsurkan Grafin dan Tiub Nano Karbon (CNT)
}

(Nanoelectromechanical Switch Devices Based on Graphene and Carbon Nanotube (CNT))

\author{
MoHD AMIR ZUlKeFli, MoHD AMBRi MOHAMED*, KIM S SiOW \& BURHANUdDIN YeOP MAJLIS
}

\begin{abstract}
ABSTRAK
Suis nanoelektromekanikal (NEM) mempunyai persamaan dengan suis konvensional semikonduktor apabila digunakan sebagai transistor dan penderia walaupun prinsip operasinya berbeza. Perbezaan prinsip operasi suis ini memberikan kelebihan kepada suis NEM untuk beroperasi dalam persekitaran yang melampau manakala suis konvensional semikonduktor mempunyai kelebihan daripada segi infrastruktur fabrikasi yang canggih. Dalam kertas ini, kami mengulas kemajuan terbaru dan potensi teknologi NEM dalam aplikasi pensuisan berdasarkan bahan berasaskan karbon seperti CNT dan grafin. Kemajuan reka bentuk geometri suis NEM seperti struktur rusuk berlubang, mempunyai kelebihan daripada segi voltan operasi peranti yang rendah, turut dibincangkan dalam kertas ini. Berdasarkan Kitaran Gemburan Gartner, teknologi, proses dan produk untuk suis NEM atau hibrid NEM-CMOS berada di takuk berbeza iaitu di jurang ilusi, cerun pencerahan dan dataran tinggi produktiviti. Kemudian, reka bentuk geometri suis NEM berasaskan bahanbahan ini diulas dengan lengkap berdasarkan kajian kepustakaan terbaru. Kami mengenal pasti cabaran yang terlibat dalam proses fabrikasi suis NEM berasaskan CNT dan grafin seperti kebocoran get dan proses litografi yang mencabar. Kesimpulannya, kami meringkaskan kertas kajian ini kepada beberapa sudut perspektif, pandangan dan peluang pada masa depan dalam teknologi suis NEM.
\end{abstract}

Kata kunci: Bahan karbon; grafin; nanoelektromekanikal (NEM); suis NEM; tiub nano karbon (CNT)

\section{ABSTRACT}

Nanoelectromechanical (NEM) switches are similar to the conventional semiconductor switches when used as a transistor and sensor, in spite of their fundamental differences in operating principles. This difference in operation allows NEM switches to perform better in harsh conditions while conventional semiconductor switch has the advantage of matured technology in fabrication. In this paper, we reviewed the recent progress and potential of NEM technology in switching applications based on carbon-based materials focusing on CNT and graphene. The progress in geometrical design like perforated beam structure, which can reduce its operation voltage, was also discussed. Based on Gartner Hype Cycle, the technology, process and product of NEM switch or hybrid NEM-CMOS switch was located at various stages such as the trough of disillusionment, slope enlightment and plateau of productivity, respectively. Then, the geometrical design of NEM switch based on these materials was reviewed from the recent literatures. We also identified the challenges involved in fabrication of CNT and graphene based NEM switch technology, such as, short channel effect, gate leakage and challenge in lithography process. Finally, we concluded this paper with a few perspectives, insights and opportunities in NEM switch technology.

Keywords: Carbon-based material; carbon nanotube (CNT); graphene; nanoelectromechanical (NEM); NEM switch

\section{PENDAHULUAN}

\section{TEKNOLOGI NEM DAN PENSUISANNYA}

Pembangunan teknologi nano membuatkan kami meneliti semula satu idea pengkomputeran mekanikal yang dicadangkan oleh Charles Babbage kira-kira dua abad yang lalu. Walaupun idea pengkomputeran mekanikal masih tidak dapat dilaksanakan secara sepenuhnya buat ketika ini kerana isu kebolehharapan yang rendah, tetapi idea ini mempunyai potensi untuk mengatasi kemajuan dalam mikro/ nanoelektronik yang selama ini diwakili oleh hukum Moore yang dicadangkan oleh Gordon Moore pada tahun 1965. Hukum Moore meramalkan bahawa dengan mengurangkan saiz komponen dalam litar berintegrasi, bilangan komponen pada litar berintegrasi ini akan meningkat dua kali ganda setiap dua belas bulan (Moore 1965). Seperkara lagi, apabila kita telah mencapai had penskalaan transistor semikonduktor, had penskalaan ini menandakan masa untuk mencipta dan mereka bentuk transistor semikonduktor yang baru (Theis \& Solomon 2012).

Kejayaan industri semikonduktor boleh dinilai berdasarkan dua faktor iaitu prestasi ketahanan mekanikal dan proses fabrikasi berskala. Oleh kerana saiz peranti semikonduktor dikurangkan kepada beberapa puluhan nanometer dan permintaan untuk lebih banyak aplikasi terus meningkat, strategi lain amat diperlukan. Sebagai contoh, 
suis NEM adalah salah satu calon untuk menyelesaikan isu penggunaan kuasa yang tinggi dalam peranti complementary metal-oxide semiconductor (CMOS) sekiranya saiz peranti dikurangkan kepada saiz nano (Dadgour \& Banerjee 2007; Peschot et al. 2015).

Suis NEM menunjukkan ciri yang sangat baik seperti nisbah buka-tutup yang tinggi, pensuisan mendadak dan pengurangan arus bocor (Kim et al. 2014, 2011). Sehubungan itu, suis NEM merupakan komponen yang menarik di dalam litar logik, geganti, penyimpanan data dan komunikasi frekuensi tinggi (Loh \& Espinosa 2012). Walau bagaimanapun, suis NEM masih tidak dapat mengatasi suis konvensional CMOS kerana beberapa mod kegagalan seperti peranti terbakar, haus dan melekat yang seterusnya meningkatkan voltan operasi dan penggunaan kuasa perantinya (Sun et al. 2016b). Sehubungan dengan itu, terdapat dua cara yang biasa digunakan untuk mengurangkan masalah yang telah disebutkan iaitu pengenalan bahan baru (Feng et al. 2010; Lee et al. 2013) dan reka bentuk geometri yang optimum (Frank et al. 2007; Qian et al. 2012).

Walaupun banyak kertas kerja akademik dan paten tentang suis NEM telah diterbitkan, kertas kajian ini akan mengkhususkan kepada kemajuan terbaru dan potensi teknologi suis NEM berdasarkan bahan-bahan alternatif yang berasaskan karbon iaitu CNT dan grafin daripada perspektif ciri bahan, kejuruteraan dan sains asas. Kami akan memfokuskan kepada daya penarikan elektrostatik sebagai contoh, voltan tarik-dalam dan voltan tarik-keluar. Di samping itu, kami mengenal pasti cabaran yang terlibat dalam proses penskalaan dan teknologi yang diperlukan untuk terus maju serta kebolehharapan peranti. Akhirnya, kami meringkaskan kajian ini kepada beberapa sudut perspektif, pandangan dan peluang untuk pembangunan teknologi suis NEM pada masa hadapan.

\section{PRINSIP ASAS OPERASI SUIS NEM DAN PENGGUNAAN KUASANYA}

Lazimnya, suis NEM beroperasi dengan menggunakan daya elektrostatik yang memesongkan unsur aktif secara mekanikal kepada penyentuhan fizikal ke arah elektrod bertentangan lantas mengubah sifat peranti. Hubungan daya elektrostatik dengan ruang udara antara unsur aktif dan elektrod adalah berkadar songsang; jadi operasi peranti semakin berkesan jika saiznya dikecilkan. Apabila voltan yang dialirkan ke seluruh unsur aktif dan elektrod meningkat, daya elektrostatik yang terhasil diseimbangkan dengan daya pemulihan kenyal. Lanjutan daripada itu, apabila voltan mencapai tahap kritikal yang dikenali sebagai voltan tarik-dalam, daya elektrostatik akan mengatasi daya pemulihan kenyal yang menyebabkan unsur aktif akan menyentuhi elektrod bertentangan, membolehkan suis terbuka seperti digambarkan di dalam Rajah 1(a). Seterusnya, apabila voltan yang dialirkan mencapai tahap pasca-kritikal yang dikenali sebagai voltan tarik-keluar, daya pemulihan kenyal pula akan mengatasi data elektrostatik yang menyebabkan usnsur aktif akan kembali kepada kedudukan asal, membolehkan suis tertutup seperti digambarkan dalam Rajah 1(b). Voltan tarik-dalam dan tarik-keluar bergantung kepada geometri peranti dan voltan ini boleh diterangkan mengikut model 1D-Lumped sebagai:

$$
\begin{aligned}
& \mathrm{V}_{\text {tarik-dalam }}=\sqrt{\frac{8 \mathrm{Kg}^{3}}{27 \varepsilon_{0} W_{b} W_{c}}} \\
& \mathrm{~V}_{\text {tarik-keluar }}=\sqrt{\frac{2 \mathrm{Kg} \mathrm{d}^{3}}{\varepsilon_{r}^{2} \varepsilon_{0} W_{b} W_{c}}} \\
& \mathrm{~K}=\frac{32 \mathrm{EW}_{\mathrm{b}} t^{3}}{L^{3}}
\end{aligned}
$$

Persamaan (1), (2) dan (3) diwakili oleh: $K$ ialah pemalar spring; $g$ ialah jurang udara; $\varepsilon_{0}$ ialah ketelusan vakum; $W_{b}$ ialah kelebaran rusuk; $W_{c}$ ialah kelebaran sentuhan; $E$ adalah modulus Young; $t$ ialah ketebalan rusuk; $L$ ialah kepanjangan rusuk; $d$ ialah ketebalan lapisan dielektrik; dan $\varepsilon_{r}$ ialah ketelusan lapisan dielektrik. Selain itu, mod-buka suis ini akan membawa kepada peningkatan mendadak dalam arus elektrik yang melalui peranti dan kebiasaannya kenaikan arus elektrik ini lebih tajam daripada kenaikan arus elektrik yang dialami oleh peranti CMOS.

Seterusnya, selepas suis ditutup, daya pemulihan kenyal pada unsur aktif akan bertindak untuk membuka kembali suis dan keadaan ini dapat dilihat seperti di dalam Rajah 1(b) namun daya lekatan pada sentuhan antara unsur aktif dan elektrod pula akan bertindak balik untuk memastikan suis sentiasa ditutup. Dalam pada itu, jika daya pemulihan kenyal tidak cukup untuk memutuskan lekatan apabila kepincangan elektrik telah dibuang sepenuhnya, maka suis akan beroperasi dalam keadaan tidak-meruap. Suis akan sentiasa dalam keadaan mod-buka walaupun tiada input voltan dikenakan. Walau bagaimanapun, jika suis direka dalam keadaan daya pemulihan kenyal mencukupi untuk mengatasi daya lekatan, suis akan dikenali sebagai suis meruap dan suis akan terbuka semula apabila kepincangan elektrik telah dikurangkan sepenuhnya.

Secara umumnya, unsur aktif yang kurang elastik dan ruang udara yang lebih besar antara unsur aktif dan elektrod, akan membawa kepada operasi meruap kerana daya pemulihan kenyal yang tinggi pada unsur aktif (Dadgour et al. 2008; Loh et al. 2011). Namun demikian, semua ini menyebabkan voltan operasi yang tinggi dan kecenderungan yang lebih besar ke arah mod kegagalan elektrohaba. Sebaliknya, unsur aktif yang elastik dan ruang udara yang kecil membawa kepada operasi tidak-meruap serta voltan operasi yang rendah.

Struktur geometri elektrod yang berbeza digunakan untuk menghasilkan fungsi yang berbeza. Sebagai contoh dalam peranti dua-terminal (2-T), kedua-dua elektrod 


$$
\begin{aligned}
& g=\text { Ruang udara } \\
& t=\text { Tebal rusuk }
\end{aligned} \quad L=\text { Panjang rusuk }
$$

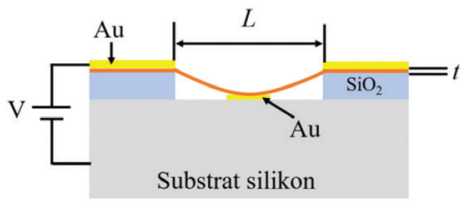

(b)

$\begin{aligned} & g=\text { Ruang udara } \\ & t=\text { Tebal rusuk }\end{aligned} \quad L=$ Panjang rusuk

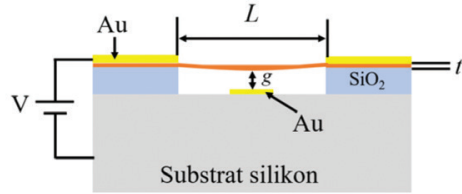

RAJAH 1. Suis NEM bagi struktur hujung terkapit dalam keadaan; a) mod-buka (b) mod-tutup

masing-masing digunakan sebagai saliran dan get untuk menarik unsur aktif menyentuh elektrod bertentangan (Sun et al. 2016a, 2014) seperti ditunjukkan di dalam Rajah 2(a) dan 2(b) manakala suis NEM yang mempunyai tiga-terminal (3-T) biasanya direka supaya elektrod get boleh menolak dan menarik unsur aktif untuk menyentuhi elektrod saliran (Jang et al. 2008, 2005; Lee et al. 2010) seperti digambarkan di dalam Rajah 2(c) dan 2(d). Suis tiga-terminal ini mempunyai persamaan dengan transistor konvensional dalam kawalan arus elektrik yang melalui peranti. Tambahan pula, fungsi tambahan bagi peranti suis boleh dicapai dengan menggunakan reka bentuk yang lebih kompleks ataupun menghubungkan dua atau lebih suis-suis NEM ini untuk membuat get logik.

Dalam pada itu, kebocoran sub-ambang iaitu kebocoran arus elektrik dalam keadaan mod-tertutup akan meningkat dengan ketara bagi peranti transistor CMOS konvensional apabila saiz perantinya dikecilkan (Dadgour \& Banerjee 2009). Berbeza dengan situasi suis 2-T NEM, apabila kebocoran sub-ambang pada peranti dalam keadaan suis terbuka dapat dikurangkan melalui terowong vakum dan arus anjakan gerakan Brownian melalui ruang fizikal antara terminal punca dan saliran. Kebiasaannya, kebocoran arus diukur daripada segi buai sub-ambang yang perlu diturunkan ke nilai yang paling rendah. Jumlah terendah untuk buai sub-ambang bagi peranti CMOS adalah $\sim 60 \mathrm{mV}$ untuk setiap dekad pada suhu bilik dan jumlah lebih rendah iaitu di bawah $3 \mathrm{mV}$ untuk setiap dekad telah dilaporkan untuk peranti-peranti NEM (Abele et al. 2005; Jang et al. 2008b). Dalam situasi suis 3-T NEM dengan elektrod get bebas dan elektrod saliran bebas pula, kebocoran get sebahagian besarnya tidak terjejas apabila suis ditutup serta masih dihadkan oleh terowong vakum dan gerakan. Oleh kerana kelebihan ini, sistem hibrid NEMCMOS diberikan perhatian sebagai salah satu cara untuk mengekalkan dan meningkatkan prestasi CMOS sambil saiz perantinya terus dikecilkan. Sebagai contoh, sistem dua peranti NEM-CMOS yang telah digunakan di dalam get dinamik OR dan ingatan capaian rawak statik (SRAM). Oleh kerana itu, peranti tunggal hibrid NEM-CMOS boleh digabungkan untuk mencipta sistem yang lebih kompleks khususnya sel- tunggal SRAM sama ada hibrid atau NEM sahaja boleh digabungkan dengan penyahkod CMOS untuk membentuk SRAM berasaskan tatasusunan boleh aturcara.

Terdapat tiga keperluan utama suis NEM di dalam peranti hibrid iaitu memberikan prestasi yang kukuh serta konsisten selepas banyak kitaran, mengekalkan voltan tarik-dalam yang rendah dan cukup kecil untuk beraksi pada peringkat yang tinggi. Di samping itu, geometri suis NEM juga perlu munasabah dalam proses fabrikasi. Dalam banyak situasi, keperluan ini menyebabkan percanggahan mengenai reka bentuk peranti terutamanya rusuk yang elastik akan mengurangkan voltan tarik-dalam tetapi terdedah kepada geseran statik yang tidak boleh dipulihkan. Namun demikian, apabila kaedah fabrikasi dipertingkatkan dan bahan alternatif diperkenalkan, permasalahan ini dapat dielakkan.

Walaupun arus kebocoran elektrik dapat dikurangkan, penggunaan kuasa peranti adalah satu faktor lagi yang perlu diberikan perhatian bagi suis NEM kerana kuasa perantinya berubah dengan frekuensi operasi dan voltan kuasa dua. Hasilnya, suis NEM selalunya menggunakan jumlah kuasa yang rendah berbanding dengan sistem CMOS pada frequensi yang rendah, namun suis NEM menjadi
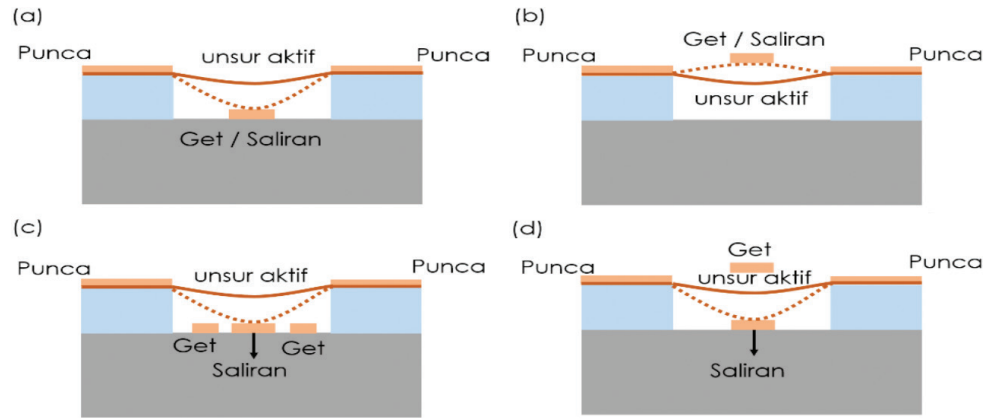

RAJAH 2. Senibina suis NEM berstruktur hujung terkapit; (a) dua-terminal dengan elektrod bahagian bawah, (b) duaterminal dengan elektrod bahagian atas, (c) tiga-terminal dengan voltan dikenakan kepada elektrod saliran dan get menghasilkan daya elektrostatik yang menarik unsur aktif untuk menyentuh elektrod saliran dan (d) tiga-terminal dengan daya elektrostatik menolak unsur aktif untuk menyentuh elektrod saliran 
kurang cekap berbanding peranti CMOS atas $~ 150$ juta operasi setiap sesaat untuk penambah 32-bit (Dadgour et al. 2010). Perkara ini secara amnya mengambil jumlah suis NEM yang kurang daripada transistor CMOS untuk membuat litar logik dalam membantu mengimbangi masalah ini ke tahap yang tertentu.

\section{BAHAN BERASASKAN KARBON (CNT DAN GRAFIN) UNTUK APLIKASI SUIS NEM}

Pada ketika ini, kebanyakan peranti didominasi oleh bahan yang berasaskan silikon kerana teknologi pukal dan teknologi permukaan mikropemesinan yang sesuai dengan pengeluaran litar berintegrasi adalah berasaskan silikon. Walau bagaimanapun, silikon mempunyai kelemahan intrinsik seperti modulus Young yang rendah, kekuatan fraktur yang lemah dan pekali geseran yang besar. Kadar kegagalan haus dan permukaan bagi geseran statik yang tinggi menghadkan silikon sebagai peranti pensuisan yang dibolehharapkan. Bahan semikonduktor yang mempunyai jurang jalur yang luas seperti silikon karbida, III-V nitrida juga telah pun digunakan untuk memfabrikasikan peranti NEM yang berprestasi tinggi (Cimalla et al. 2007). Namun demikian, sifat mekanikal bahan-bahan ini adalah lebih rendah daripada bahan berasaskan karbon seperti CNT dan grafin.

Karbon merupakan elemen yang boleh membentuk beberapa orbital atom menghibrid seperti empat kali ganda ikatan tetrahedron kristal $\mathrm{sp}^{3}$ serta intan amorfus, tiga kali ganda ikatan bersatah $\mathrm{sp}^{2}$ dan CNT. Bahan berasaskan karbon ini mempunyai kekerasan mekanikal yang tinggi, kestabilan kimia yang baik, jisim yang rendah, ciri kekonduksian haba yang tinggi yang menjadikannya bahan yang sesuai untuk aplikasi suis NEM. Bahan berasaskan karbon ini mempunyai permukaan hidrofobik yang dapat mengurangkan masalah permukaan geseran statik antara sentuhan. Geseran statik adalah masalah yang menyebabkan kegagalan awal peranti suis NEM dan sebahagian besarnya adalah hasil daripada daya kapilari antara permukaan hidrofilik serta interaksi jarak dekat seperti daya van der Waals. Penggunaan bahan berasaskan karbon di dalam suis NEM boleh mengelak daripada reka bentuk peranti yang kompleks atau penyalutan permukaan. Oleh sebab itu, suis NEM boleh dijalankan dengan menggunakan bahan-bahan berasaskan karbon.

\section{TEKNOLOGI SUIS NEM BERASASKAN KARBON (CNT DAN GRAFIN): GAMBARAN KESELURUHAN}

Lazimnya, geometri CNT boleh dianggap sebagai lapisan ikatan $\mathrm{sp}^{2}$ grafin yang digulung menjadi tiub berongga yang panjang. Seperti yang kita boleh lihat CNT berdinding tunggal (SWCNT) dikategorikan sebagai gulungan grafin monolapisan dan sifat SWCNT bergantung kepada bagaimana bahan SWCNT ini digulungkan. Perkara ini boleh diterangkan oleh vektor khi $C=n a+m b$ dengan integer $n$ dan $m$ adalah bilangan unit vektor $(a, b)$ di dalam kekisi heksagon manakala indeks $(n, m)$ pula menentukan kekhian serta diameter SWCNT. Apabila nilai integer $n=m$, bahan tersebut merupakan CNT berjenis kerusi lengan dan sekiranya nilai integer $m=0$, bahan tersebut menunjukkan CNT berjenis berliku-liku. Sekiranya CNT berjenis kerusi lengan, maka ia merupakan bahan bersifat logam manakala yang lain pula adalah semikonduktor atau separa semikonduktor. CNT berbilang dinding (MWCNT) pula merupakan tiub yang terdiri daripada berbilang lapisan grafin dan MWCNT selalunya bersifat logam. Diameter MWCNT berbeza daripada beberapa ratus nanometer dan panjangnya pula berbeza nilainya dari kurang 1 mikron sehingga milimeter. Oleh kerana itu, CNT mempunyai konfigurasi unik yang menyebabkan pelbagai ciri elektronik serta elektromekanikal yang baik. Ciri yang baik ditambah dengan dimensi dan jisim yang rendah membuatkan CNT merupakan salah satu bahan yang menarik untuk aplikasi NEM. Oleh kerana itu, pelbagai peranti NEM berasaskan CNT telah dilaporkan seperti resonator berfrekuensi tinggi $(\mathrm{GHz})$, sensor anjakan dan sensor jisim beresolusi atom (Jensen et al. 2008; Li et al. 2004; Stampfer et al. 2006).

Dalam pada itu, grafin merupakan salah satu bahan dua dimensi yang merupakan satu lapisan karbon atom dengan struktur kekisi heksagon $\mathrm{sp}^{2}$ serta bahan grafin merupakan blok binaan asas untuk bahan grafit yang lain seperti kosong-dimensi fullerene, satu-dimensi CNT dan tiga-dimensi grafit pukal. Tambahan pula, teori termodinamik yang lalu mendedahkan bahawa grafin mandiri akan menjadi tidak stabil dan akan tergulung menjadi CNT atau struktur melengkung yang lain. Semua ini berlaku sehingga tahun 2004 apabila grafin telah ditemui secara proses pengelupasan mekanikal oleh Andre Geim dan Konstantin Novoselov (Novoselov et al. 2004). Penemuan ini merevolusikan pandangan terdahulu yang mengatakan grafin tidak stabil dalam keadaan mandiri. Seterusnya, penemuan tersebut menyebabkan penganugerahan hadiah Nobel kepada mereka pada tahun 2010. Bukan itu sahaja malah penemuan tersebut menarik perhatian para penyelidik, saintis dan jurutera seluruh dunia kerana sifatnya yang unggul misalnya modulus Young yang tinggi $~ 1$ TPa (Geim \& Novoselov 2007), mobiliti elektron yang melebihi $200,000 \mathrm{~cm}^{2} / \mathrm{V} . \mathrm{s}$ (Bolotin et al. 2008; Zulkefli et al. 2016), ketebalan yang sangat nipis $\sim 0.335 \mathrm{~nm}$, rintangan yang rendah $\sim 1 \mu \Omega$-cm (Liu et al. 2014) dan keupayaan membawa arus elektrik yang cemerlang $\sim 10^{8} \mathrm{~A} / \mathrm{cm}^{2}$ (Murali et al. 2009). Oleh kerana sifat yang dinyatakan dan kewujudan grafin yang stabil dalam keadaan mandiri, grafin adalah salah satu calon bahan yang sesuai untuk memfabrikasi suis NEM yang berprestasi tinggi daripada segi ketahanan mekanikal yang lebih baik serta voltan operasi yang rendah (Shi et al.2012) lantas boleh mengurangkan masalah yang dihadapi oleh suis konvensional semikonduktor.

Dalam pada itu, Jadual 1 menyenaraikan sifat fizikal bahan berasaskan karbon iaitu CNT dan grafin untuk teknologi NEM dan dibandingkan dengan bahan intan, silikon, silikon karbida dan aluminium nitrat seterusnya mendedahkan kelebihan bahan CNT dan grafin untuk aplikasi NEM. Bahkan juga, kami akan mengkaji semula 
JADUAL 1. Ciri mekanikal dan elektrikal bahan berasaskan karbon dengan silikon dan bahan-bahan lain (Amaratunga 2002;

Balandin et al. 2008; Hopcroft et al. 2010; Krishnan et al. 1998; Liao \& Koide 2011; Siow 2017; Yavari et al. 2010)

\begin{tabular}{|c|c|c|c|c|c|c|}
\hline Ciri & Silikon & Silikon karbida & $\begin{array}{c}\text { Aluminium } \\
\text { nitrat }\end{array}$ & Intan & SWCNT & Grafin \\
\hline Modulus Young (GPa) & 130 & 450 & $100-400$ & 1200 & $\sim 1000$ & $\sim 1000$ \\
\hline Mobiliti elektron $\left(\mathrm{cm}^{2} / \mathrm{V} \cdot \mathrm{s}\right)$ & 1450 & 900 & 426 & 4500 & 100,000 & 200,000 \\
\hline Mobiliti lubang $\left(\mathrm{cm}^{2} / \mathrm{V} \cdot \mathrm{s}\right)$ & 480 & 120 & 14 & 3800 & 4,000 & $>100,000$ \\
\hline Pekali geseran & $0.4-0.6$ & $0.2-0.5$ & 0.4 & $<0.05$ & $0.01-2$ & $0.07-0.5$ \\
\hline Ketumpatan $\left(\mathrm{g} / \mathrm{cm}^{3}\right)$ & 2.33 & 3.21 & 53 & 3.52 & $1.3-1.4$ & $>1$ \\
\hline Kekonduksian haba $(\mathrm{W} / \mathrm{cm} \cdot \mathrm{K})$ & 1.5 & 5 & 1.75 & 24 & 66 & 53 \\
\hline Jurang jalur (eV) & 1.1 & 3.3 & 6.2 & 5.5 & $0-2$ & $\sim 0$ \\
\hline Kekuatan fraktur (GPa) & 1 & 5.2 & 0.29 & 5.3 & $13-55$ & - \\
\hline Kekerasan (GPa) & 10 & 33 & 11.8 & 100 & - & - \\
\hline Bidang penguraian $(\mathrm{MV} / \mathrm{cm})$ & 0.3 & 3.5 & 1.5 & 10 & - & - \\
\hline Pemalar dielektrik & 11.8 & 9.7 & 8.9 & 5.5 & - & - \\
\hline
\end{tabular}

secara terperinci ciri-ciri bahan, proses fabrikasi dan penggunaan bahan CNT dan grafin untuk aplikasi suis NEM.

\section{CIRI-CIRI BAHAN}

\section{MEKANIKAL}

Modulus Young merupakan salah satu parameter yang penting untuk peranti NEM. Sebagai contoh, ciri-ciri bahan CNT dan grafin mempamerkan kepelbagaian jika dibandingkan dengan bahan lain seperti intan. Sebagai contoh, CNT dan grafin dijangka mempunyai kekerasan yang tinggi kerana ikatan karbon-karbon $\mathrm{sp}^{2}$. Eksperimen berangka dan kerja pemodelan telah dijalankan untuk menentukan nilai modulus Young CNT dan grafin. Nilai modulus Young adalah tinggi daripada 250-1800 GPa yang sangat sesuai untuk digunakan di dalam aplikasi suis NEM yang berprestasi tinggi.

Kesimpulannya, kekuatan mekanikal untuk keduadua bahan ini, CNT dan grafin banyak bergantung kepada kualiti bahan tersebut. Nilai kekuatan mekanikal yang bersesuaian untuk digunakan di dalam aplikasi suis NEM banyak bergantung kepada faktor yang lain kerana prestasi peranti tidak bergantung kepada modulus Young sahaja tetapi melibatkan banyak faktor seperti reka bentuk peranti. Sebagai contoh, kita mengambil kira prestasi peranti daripada segi voltan operasi sahaja yang hanya memerlukan nilai kekuatan mekanikal antara 250 - $800 \mathrm{GPa}$ untuk mendapatkan nilai voltan tarik-dalam di bawah $2 \mathrm{~V}$ dengan ketebalan grafin ditetapkan hanya satu lapisan dan rusuk grafin berstruktur hujung terkapit. Ringkasan bagi nilai modulus Young untuk kepelbagaian bahan CNT, grafin, silikon dan bahan-bahan lain dapat dilihat dalam Rajah 3.

\section{ELEKTRIKAL}

Sifat elektrik CNT banyak berkaitan dengan struktur intrinsik CNT, kecacatan dan getaran kekisi yang berselerak di dalam tiub serta antara-muka di antara tiub dan sentuhan logam. Oleh kerana sifat satu dimensi CNT dan ikatan kovalennya yang kuat, interaksi CNT dengan elektrod

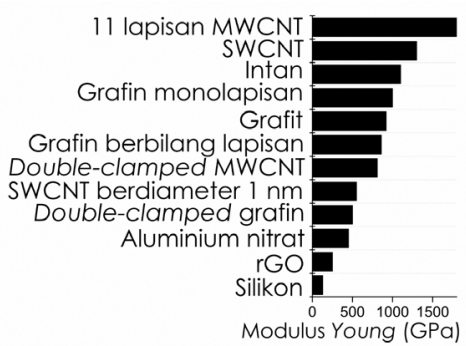

RAJAH 3. Perbandingan nilai modulus Young bagi intan, CNT, grafin, silikon, rGO (grafit terturun) dan aluminium nitrat

logam makroskopik membawa kepada kekonduksian kuantum lantas kekonduksian CNT boleh menjadi lebih baik daripada kuprum. Rintangan untuk CNT boleh digambarkan sebagai:

$$
R=h /\left(2 e^{2} M\right)
$$

Persamaan (4) diwakili oleh; $h$ ialah pemalar Planck, $e$ adalah caj elektron dan $M$ adalah bilangan mod dalam CNT dengan tenaga antara aras Fermi elektrod (Avouris et al.2007). Di samping itu, Tans et al. (1997) mengukur kekonduksian elektrik untuk SWCNT bersifat logam menggunakan prob dua-titik yang menunjukkan nilai rintangan CNT dalam puluhan $\mathrm{k} \Omega$ serta nilai rintangan antara-muka elektrod sebanyak $1 \mathrm{M} \Omega$.

Dalam pada itu, grafit pukal dikenali sebagai konduktor yang sangat baik dengan kerintangan yang rendah antara 9-40 $\mu \Omega$.m manakala grafin pula dianggap sebagai semikonduktor dengan sela jalur yang bernilai sifar (Yavari et al. 2010). Sifat elektrikal grafin bergantung kepada kaedah penyediaan bahan misalnya grafin terkelupas daripada grafit pukal menunjukkan sifat elektrik dan elektronik yang terbaik. Ukuran pengangkutan mendedahkan bahawa grafin yang dikelupas secara mekanikal mempamerkan mobiliti elektron yang tinggi $\left(>200,000 \mathrm{~cm}^{2} / \mathrm{V} \cdot \mathrm{s}\right)$ pada suhu bilik dengan ketumpatan elektron $2 \times 1011 \mathrm{~cm}^{-2}$ (Bolotin et al. 2008). Bukan itu sahaja malah pergerakan elektron 
ini tidak bergantung pada suhu disebabkan mekanisme kecacatan berselerak manakala rintangan elektrik bagi lapisan grafin pula berjumlah $10^{-8} \Omega$.m iaitu kurang daripada rintangan elektrik bahan perak. Murali et al. (2009) mengukur rintangan grafin berbilang lapisan dengan menggunakan e-beam litografi untuk membina elektrod dan memfabrikasikan peranti yang terdiri daripada grafin nanoreben. Grafin nanoreben ini dengan kelebaran $16 \mathrm{~nm}$ mempunyai kapasiti membawa arus sekitar $10^{8} \mathrm{~A} / \mathrm{cm}^{2}$ yang merupakan seribu kali lebih tinggi daripada kuprum. Kapasiti membawa arus elektrik yang tinggi menyebabkan pensuisan peranti berlaku dengan pantas. Oleh kerana kelebihan ini, bahan CNT dan grafin merupakan calon bahan yang sesuai untuk digunakan dalam aplikasi yang menggunakan daya permukaan yang rendah kerana nilai pekali geserannya yang rendah berbanding silikon, silikon karbida dan aluminium nitrat. Selain itu, kedua-dua bahan ini juga mempunyai mobiliti elektron yang tinggi berbanding silikon, silikon karbida dan aluminium nitrat yang menunjukkan kebolehharapan membawa arus yang tinggi seterusnya meningkatkan kelajuan pensuisan.

\section{TEKNOLOGI SUIS NEM}

\section{SUIS NEM BERASASKAN CNT}

Bagi suis NEM CNT pula, beberapa usaha kajian berasaskan teori bagi suis NEM CNT mendedahkan bahawa terdapat ruang yang besar untuk diterokai dalam proses mereka bentuk bagi aplikasi yang berpotensi seperti peranti logik, elemen ingatan dan penguat (Jang et al. 2008a). Sebagai contoh, peranti nano-tweezers CNT yang boleh dianggap sebagai suis 2-T telah dilaporkan oleh Kim dan Lieberl pada tahun 1999. Pada masa ini, kebanyakan suis adalah 3-T seperti transistor kesan-medan (FET) yang mengandungi get, punca dan saliran dan struktur untuk peranti suis CNT boleh berjenis hujung terkapit atau rusuk jalur. Dalam pada itu, bahan CNT selalu digantungkan di atas substrat $\mathrm{SiO}_{2} / \mathrm{Si}$ dan disambungkan dengan elektrod punca. Apabila voltan dialirkan pada get, cas akan terhasil pada tiub dan permukaan get, seterusnya hasil daripada daya elektrostatik akan membengkokkan tiub untuk menyentuh elektrod saliran dan mengubah keadaan buka-tutup peranti. Lee et al. (2004) yang pertama kali mengkaji peranti geganti 3-T MWCNT yang difabrikasi melalui teknik dielektroforesis (DEP) dan peranti ini adalah salah satu contoh suis jalur terawal berasaskan bahan CNT. Peranti ini difabrikasikan dengan melekatkan dua bahan CNT pada elektrod bebas yang dihasilkan di atas pipet-mikro-kaca-tertarik. Sama seperti tweezers yang digunakan dalam kehidupan harian, nano-tweezers CNT ini boleh memegang dan memanipulasi kelompok submikron dan dawai nano. Peranti ini berfungsi dengan memesongkan dua rusuk jalur CNT yang digerakkan oleh daya elektrostatik di antara rusuk jalur CNT dengan elektrod. Berbeza daripada sistem biasa NEM yang hanya satu bahagian bergerak bagi satu peranti namun bagi situasi ini, kedua-dua rusuk jalur CNT boleh memesong bersama-sama. Seperkara lagi, voltan penarikan bagi peranti ini dilaporkan setinggi $\sim 8.5 \mathrm{~V}$.

Berdasarkan kajian lain pada nano-tweezers, Jang daripada kumpulan Amaratunga menunjukkan pensuisan NEM daripada peranti yang sama (Jang et al. 2005) dengan bahan rusuk jalur CNT menegak ditumbuhkan secara in situ di atas titik pemangkin nikel melalui proses bawah-atas pemendapan wap kimia (CVD). Dengan cara ini, proses fabrikasi peranti tatasusunan dan persepaduan yang besar dapat dijalankan. Namun demikian, peranti asalnya telah dilaporkan pada tahun 2005 yang mempunyai voltan tarik-dalam setinggi $\sim 24 \mathrm{~V}$ namun nilainya menurun ke $\sim 4.5 \mathrm{~V}$ selepas proses pembaikan dijalankan (Jang et al. 2008). Tambahan pula, suis rusuk jalur menegak NEM menunjukkan potensi besar dalam aplikasi sistem RF NEM, sel-sel memori yang tidak-meruap, peranti logik dan transistor mekanikal.

Dalam pada itu, berbeza pula dalam situasi suis 3-T NEM daripada MWCNT dalam geometri mendatar yang dilaporkan oleh Lee et al. (2004) dengan suis peranti ini memesongkan jalur CNT dengan voltan get untuk menyentuh elektrod saliran. Sejajar dengan itu, ciri lengkuk arus-voltan (I-V) untuk geganti CNT yang digantung $80 \mathrm{~nm}$ di atas elektrod get dan saliran telah menunjukkan peningkatan arus elektrik yang tidak selari apabila voltan get meningkat dengan $\mathrm{V}_{\text {punca-get }}<20 \mathrm{~V}$. Namun demikian, peningkatan arus elektrik yang selari dan turun-naik yang kukuh dapat dilihat untuk $\mathrm{V}_{\text {punca-get }}>$ $20 \mathrm{~V}$. Beberapa kesan histerisis juga dapat dilihat pada pemulihan alur CNT apabila pengurangan voltan get yang mungkin digunakan untuk aplikasi memori tidak-meruap.

Dalam situasi yang berbeza, apabila struktur bahan CNT diapit di kedua-dua hujungnya, bahan CNT mempamerkan ketegangan yang lebih tinggi selepas pemesongan lantas meningkatkan daya pemulihan dan kadar tindak balasnya. Kajian mengenai kelajuan pensuisan suis SWCNT NEM yang berstruktur hujung terkapit menunjukkan bahawa suis CNT ini adalah tiga kali lebih cepat magnitudnya berbanding suis MEM dengan masa pensuisan selama $2.8 \mathrm{~ns}$ serta voltan tarik-dalam berjumlah kurang daripada 5 V. Selain itu, beberapa penyelidik lain juga menggunakan suis NEM berasaskan tatasusunan CNT mendatar secara menjajar yang menunjukkan sifat pensuisan yang sama (Jang et al. 2005). Berdasarkan kajian sebelum ini, struktur rusuk jalur suis NEM berbilang lapisan CNT tidak sesuai untuk aplikasi voltan operasi yang rendah di bawah nilai $2 \mathrm{~V}$ kerana kebolehharapan suis yang rendah manakala struktur hujung terkapit pula mempunyai potensi voltan operasi yang kurang daripada $2 \mathrm{~V}$ dengan kebolehharapan yang lebih tinggi daripada struktur suis rusuk jalur. Selain itu, monolapisan CNT sangat sesuai untuk digunakan dalam aplikasi pensuisan di bawah 3.0 ns jika dibandingkan dengan berbilang lapisan CNT yang kelajuan pensuisannya yang perlahan. 


\section{SUIS NEM BERASASKAN GRAFIN}

Suis NEM berasaskan grafin yang pertama telah dibangunkan oleh kumpulan Jing Kong dari The Massachusetts Institute of Technology (MIT) (Milaninia et al. 2009) yang difabrikasikan dengan pemendapan dua lapisan grafin yang dipisahkan oleh jurang udara sebanyak $500 \mathrm{~nm}$. Lapisan atas dipunarkan kepada $3 \mu \mathrm{m}$ lebar julur yang tergantung di atas $20 \mu \mathrm{m}$ lebar parit seterusnya bahan grafin menyentuh lapisan bawah dengan mengenakan voltan sebanyak $5 \mathrm{~V}$. Suis pertama NEM berasaskan grafin berfungsi dengan kebolehharapan yang rendah disebabkan oleh kelusuhan pada struktur CVD grafin selepas beberapa kali pensuisan.

Penyelidik terdahulu telah melaporkan suis grafin terkelupas 3-T menggunakan geometri yang sama dengan kumpulan Jing Kong dari MIT tetapi dengan perbezaan daripada segi keluasan elektrod emas iaitu $100 \mathrm{~nm}^{2}$ serta saiz parit $2 \times 0.15 \mu \mathrm{m}$ (Shi et al. 2012). Peranti ini turut mengalami kegagalan pemulihan disebabkan oleh daya van der Waals walaupun elektrodnya hanya berkeluasan 100 $\mathrm{nm}^{2}$. Di samping itu, peranti berasaskan grafin monolapisan pula tidak akan pulih melainkan keluasan dawai emas yakni elektrod yang digunakan kurang daripada $5 \mathrm{~nm}^{2}$. Kajian tersebut digunakan dengan reka bentuk suis NEM berasaskan grafin berbilang lapis dengan kaedah sentuhan titik serta melalui analisa kuantitatif daya van der Waals pada grafin dan daya pemulihan dengan melekatkan serta mencabutkan grafin menggunakan tip AFM (Kim et al. 2011).

Kajian mengenai kekukuhan mekanikal bagi grafin monolapisan turut dijalankan dan mendapati bahawa grafin monolapisan sangat mudah untuk lusuh menjadikan grafin monolapisan tidak mempunyai kebolehharapan yang tinggi jika dibandingkan dengan suis grafin berbilang lapis. Oleh itu, penggunaan kaedah sentuhan titik bagi suis grafin berbilang lapis menunjukkan bahawa potensi untuk kebolehharapan yang lebih tinggi. Dalam pada itu, STM- proba telah digunakan dengan $150 \mathrm{~nm}^{2}$ kawasan sentuhan yang membawa kepada $60 \mathrm{nN}$ daya antara proba dan grafin dengan $15 \mathrm{~V}$ voltan ambang. Suis sentuhan titik ini boleh beroperasi sehingga 500 kitaran iaitu yang paling tinggi pernah dilaporkan. Namun demikian, pembaikan daripada segi proses fabrikasi telah dijalankan dengan menggantungkan julur CVD grafin di atas parit yang lebih kecil dengan $150 \mathrm{~nm}$ kedalaman serta $20 \mu \mathrm{m}$ kelebaran dan suis grafin ini boleh beroperasi dengan voltan penarikan pada $1.85 \mathrm{~V}$ yang serasi dengan keperluan litar konvensional CMOS. Bukan itu sahaja malah suis ini mempunyai sifat buka/tutup yang mendadak serta menunjukkan tindak balas yang pantas.

Berbeza daripada mekanisme suis yang mempunyai struktur hujung terkapit, suis grafin yang dibangunkan oleh kumpulan Marc Bockrath beroperasi berdasarkan pembentukan dan pemutusan ikatan atom karbon yang menyambung dengan persimpangan putusan grafin (Standley et al. 2008). Secara geometrinya, ia seperti suis sisi dan suis-suis ini difabrikasikan dengan mewujudkan jurang berskala nano yang menggunakan penguraian elektrikal bagi kepingan grafin serta proses ini merupakan proses swa-mengehad boleh-harap yang dapat mengelakkan keperluan penggunaan teknik litografi maju.

Terdapat kajian dan proses fabrikasi mengenai suis NEM berasaskan grafin yang ditumbuhkan terus di atas peranti substrat tanpa proses permindahan dan juga penggunaan elektrod bahagian atas sebagai elektrod penarik. Semua ini dapat menjimatkan kos operasi dan mengurangkan kecacatan grafin yang disebabkan oleh proses permindahan (Sun et al. 2016a, 2016b). Namun demikian, sebanyak $50 \%$ peranti sahaja yang boleh berfungsi dengan baik dan hanya grafin berbilang lapisan sahaja yang dapat ditumbuhkan serta grafin ini tidak meliputi keseluruhan elektrod untuk berfungsi sebagai suis. Kajian sistematik ke atas keadaan pertumbuhan serta reka bentuk geometri yang optimum sangat berguna untuk meningkatkan prestasi dan fungsi suis grafin NEM melalui pertumbuhan terus di atas substrat peranti.

Ringkasan untuk suis NEM berasaskan bahan grafin ini dipaparkan di dalam Jadual 2. Jadual 2 menunjukkan suis berstruktur monolapisan grafin mempunyai nilai voltan tarik-dalam yang rendah berbanding suis berstruktur berbilang lapisan grafin. Grafin tergantung yang berbentuk bulatan pula tidak sesuai untuk digunakan di dalam suis NEM kerana faktor kitaran pensuisan yang rendah. Di samping itu, struktur grafin hujung terkapit adalah lebih kukuh berbanding struktur rusuk jalur.

Kesimpulannya, berdasarkan nilai voltan tarik-dalam untuk suis NEM berasaskan bahan-bahan CNT dan grafin seperti dalam Rajah 4, penggunaan bahan SWCNT sama ada suis 3-T atau pun 2-T, grafin berbilang lapisan melalui pertumbuhan terus dan grafin monolapisan sangat sesuai untuk digunakan dalam aplikasi pensuisan yang rendah iaitu di bawah $5 \mathrm{~V}$.

\section{CABARAN PENSKALAAN DAN TEKNOLOGI}

Pertama, senarai peranti suis NEM berasaskan CNT dan grafin yang dibincangkan dalam kertas kerja ini merupakan demonstrasi berskala makmal dan bukanlah demonstrasi peranti berskala besar-besaran. Selain itu, terdapat jurang besar antara prestasi yang dijangka oleh proses pemodelan atau simulasi dengan prestasi sebenar peranti. Dalam banyak kes, jurang perbezaan ini adalah disebabkan oleh kekurangan teknik fabrikasi semasa yang menghalang peranti makmal berfungsi menggunakan geometri atau bahan-bahan yang optimum. Proses fabrikasi ini memerlukan proses bersiri seperti keperluan e-beam litografi untuk menentukan dan mencorakkan elektrod serta unsur aktif yang tidak sesuai dengan pengeluaran wafer berskala. Kebimbangan dalam proses fabrikasi juga diambil perhatian dalam reka bentuk peranti lain seperti peranti keadaan pepejal yang dibuat daripada dawai nano (Cui \& Lieber 2001) atau tiub nano karbon (Franklin \& Chen 2010), resonans NEM (Eichler et al. 2011) dan grafin (Schwierz 2010).

Walaupun terdapat usaha untuk meningkatkan prestasi teknik litografi, pemendapan dan punaran, terdapat satu 
JADUAL 2. Ringkasan kemajuan teknologi suis NEM berasaskan grafin

\begin{tabular}{|c|c|c|c|c|c|c|c|}
\hline Bahan utama & Struktur peranti & $\begin{array}{c}\text { Kebocoran } \\
\text { arus elektrik }\end{array}$ & $\begin{array}{c}\text { Kitaran } \\
\text { pensuisan }\end{array}$ & $\begin{array}{l}\text { Voltan tarik- } \\
\text { dalam (V) }\end{array}$ & Kelajuan & $\begin{array}{c}\text { Mod } \\
\text { kegagalan }\end{array}$ & Rujukan \\
\hline $\begin{array}{l}\text { Grafin dwi-lapisan } \\
\quad \text { (pertumbuhan } \\
\text { melalui proses CVD) }\end{array}$ & $\begin{array}{l}\text { 3-T konduktif, } \\
\text { mendatar (hujung } \\
\text { terkapit) }\end{array}$ & $0.1 \mu \mathrm{A}$ at $4 \mathrm{~V}$ & Beberapa kali & 4.5 & - & Koyakan & $\begin{array}{c}\text { (Milaninia et } \\
\text { al. 2009) }\end{array}$ \\
\hline $\begin{array}{l}\text { Grafin berbilang } \\
\text { lapisan (pertumbuhan } \\
\text { melalui proses CVD) }\end{array}$ & $\begin{array}{l}\text { 2-T konduktif, } \\
\text { mendatar (hujung } \\
\text { terkapit) }\end{array}$ & $\mathrm{pA}$ at $4 \mathrm{~V}$ & Beberapa kali & 7 & - & - & $\begin{array}{l}\text { (Wei et al. } \\
\text { 2009) }\end{array}$ \\
\hline $\begin{array}{l}\text { Grafin berbilang } \\
\text { lapisan (pertumbuhan } \\
\text { di atas substrat nikel } \\
\text { melalui proses CVD) }\end{array}$ & $\begin{array}{l}\text { 2-T konduktif, } \\
\text { mendatar (hujung } \\
\text { terkapit) }\end{array}$ & - & $\sim 6$ kali kitaran & $\sim 1.85 \mathrm{~V}$ & $40 \mathrm{~ns}$ & Geseran statik & $\begin{array}{l}\text { (Kim et al. } \\
\text { 2011) }\end{array}$ \\
\hline $\begin{array}{l}\text { Grafin berbilang } \\
\text { lapisan melalui } \\
\text { pengelupasan } \\
\text { mekanikal }\end{array}$ & $\begin{array}{l}\text { 2-T konduktif, } \\
\text { mendatar (hujung } \\
\text { terkapit) }\end{array}$ & - & 500 kali kitaran & $\sim 25 \mathrm{~V}$ & $5.2 \mathrm{~ns}$ & Geseran statik & $\begin{array}{c}\text { (Shi et al. } \\
\text { 2012) }\end{array}$ \\
\hline $\begin{array}{l}\text { Grafin monolapisan } \\
\text { (pertumbuhan di } \\
\text { atas substrat kuprum } \\
\text { melalui proses CVD) }\end{array}$ & $\begin{array}{l}\text { 3-T konduktif, } \\
\text { bulatan }\end{array}$ & - & $\begin{array}{c}10-30 \text { kali } \\
\text { kitaran }\end{array}$ & $\sim 3 \mathrm{~V}$ & - & - & $\begin{array}{l}\text { (Liu et al. } \\
\text { 2014) }\end{array}$ \\
\hline $\begin{array}{l}\text { Grafin dwi-lapisan } \\
\text { melalui pengelupasan } \\
\text { mekanikal }\end{array}$ & $\begin{array}{l}\text { 2-T konduktif, } \\
\text { mendatar (hujung } \\
\text { terkapit) }\end{array}$ & $\sim 3 \mathrm{pA}$ & $\begin{array}{l}\text { Beberapa kali } \\
\text { kitaran }\end{array}$ & $\sim 1.85 \mathrm{~V}$ & - & $\begin{array}{c}\text { Geseran } \\
\text { statik dan } \\
\text { pembentukan } \\
\text { ikatan C-Au } \\
\text { pada tempat } \\
\text { sentuhan }\end{array}$ & $\begin{array}{l}\text { (Sun et al. } \\
\text { 2014) }\end{array}$ \\
\hline $\begin{array}{l}\text { Grafin monolapisan } \\
\text { dan berbilang lapisan } \\
\text { (pertumbuhan di } \\
\text { atas substrat kuprum } \\
\text { melalui proses CVD) }\end{array}$ & $\begin{array}{l}\text { 2-T konduktif, } \\
\text { mendatar (hujung } \\
\text { terkapit) }\end{array}$ & - & $>5000$ kali & $\sim 1-2 \mathrm{~V}$ & $\sim 100 \mathrm{~ns}$ & - & $\begin{array}{c}\text { (Li et al. } \\
\text { 2014) }\end{array}$ \\
\hline $\begin{array}{c}\text { Grafin berbilang } \\
\text { lapisan (pertumbuhan } \\
\text { di atas substrat nikel } \\
\text { melalui proses CVD) }\end{array}$ & $\begin{array}{l}\text { 2-T berkapasitor, } \\
\text { (hujung terkapit) }\end{array}$ & - & - & $10 \mathrm{~V}$ & $1.55 \mu \mathrm{s}$ & Retak & $\begin{array}{c}\text { (Moldovan et } \\
\text { al. 2015) }\end{array}$ \\
\hline $\begin{array}{l}\text { Grafin berbilang } \\
\text { lapisan (pertumbuhan } \\
\text { terus di atas substrat } \\
\text { peranti melalui } \\
\text { proses CVD) }\end{array}$ & $\begin{array}{l}\text { 2-T konduktif, } \\
\text { mendatar (hujung } \\
\text { terkapit) }\end{array}$ & $\sim 1 \mathrm{pA}$ & 20 kali kitaran & $\sim 2.7 \mathrm{~V}$ & - & Geseran statik & $\begin{array}{l}\text { (Sun et al. } \\
\text { 2016b) }\end{array}$ \\
\hline
\end{tabular}

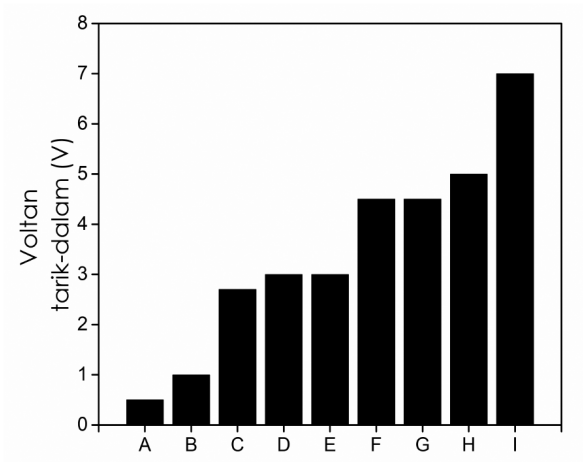

$\mathrm{A}=$ SWCNT (double-clamped: $2 T)$.

$\mathrm{B}=$ Grafin monolapisan (double-clamped).

$\mathrm{C}=$ Grafin berbilang lapisan (double-clamped)

pertumbuhan terus di atas substrat peranti.

$\mathrm{D}=\mathrm{SWCNT}$ (double-clamped: $3 T$ ).

$\mathrm{E}=$ MWCNT (double-clamped) .

$\mathrm{F}=$ MWCNT menegak (vertical-aligned).

$\mathrm{G}=$ Grafin dwi-lapisan (double-clamped).

$\mathrm{H}=$ MWCNT berusuk jalur (cantilever).

$\mathrm{I}=$ Grafin berbilang lapisan (double-clamped).

RAJAH 4. Perbandingan untuk nilai voltan tarik-dalam bagi suis NEM yang berasaskan karbon 
halangan yang besar dalam penskalaan fabrikasi suis NEM iaitu kekurangan teknik yang dapat mengawal pemposisian unsur aktif dalam kuantiti yang banyak (Loh \& Espinosa 2012). Bagi uji kaji berskala makmal pula, jumlah unsur aktif yang kecil kebiasaannya terserak secara rawak di atas substrat dengan topeng biasa tidak boleh digunakan untuk menakrifkan sentuhan elektrik. Sekiranya proses pemposisian unsur aktif dapat dikawal, maka alatan penskalaan daripada industri semikonduktor sedia ada boleh digunakan bagi menggantikan proses bersiri makmal pada ketika ini.

Selain itu, penskalaan ke atas proses fabrikasi suis NEM memerlukan kemajuan dan peningkatan dalam teknik pencorakan, pertumbuhan bahan unsur aktif yang berskala besar dan juga teknik permindahan. Walau bagaimanapun, setelah kaedah ini dapat dibangunkan secara optimum bagi membina struktur unsur aktif yang bagus, semua ini boleh mengambil terus kelebihan daripada teknik fabrikasi sedia ada. Sebagai contoh, teknik litografi resolusi tinggi dan teknologi selaput nipis manakala pemilihan bahan pula mempunyai kesan yang mendalam pada prestasi peranti. Tambahan pula, rintangan sentuhan adalah satu faktor penting yang perlu diberikan perhatian dalam memfabrikasikan peranti berprestasi tinggi yang ditentukan oleh gabungan unsur aktif dan bahan elektrod. Sebagai contoh, rintangan sentuhan yang tinggi membantu mengurangkan kegagalan disebabkan oleh nyahcas elektrikal. Namun demikian, semua ini meningkatkan lengah elektrikal dan penggunaan kuasa serta mengurangkan kestabilan peranti contohnya situasi sentuhan CNT dengan emas mempunyai rintangan sentuhan lebih kurang $\sim 1 \mathrm{k} \Omega$ manakala sentuhan CNT dengan karbon seperti berlian mempunyai lebih tinggi rintangannya iaitu lebih kurang $\sim \mathrm{G} \Omega$ (Loh et al. 2012). Proses pengoptimuman bagi rintangan sentuhan pula adalah penting kepada pembangunan peranti berasaskan suis NEM dan walaupun beberapa pengajaran dapat diambil berdasarkan kebolehharapan proses fabrikasi berskala besar untuk suis mikro, proses pengoptimuman ini juga perlu mengambil kira perubahan dalam sifat-sifat bahan yang berlaku dalam skala nano.

Seterusnya, modulus Young untuk unsur aktif juga penting contohnya nilai yang tinggi akan membawa kepada frekuensi semula jadi yang tinggi lantas mencepatkan tindak balasnya tetapi nilai modulus Young yang tinggi pula akan membawa kepada voltan tarik-dalam yang tinggi. Modulus Young bagi beberapa bahan adalah antara ratusan GPa untuk silikon (Hopcroft et al. 2010) dan silikon karbida kepada $1 \mathrm{TPa}$ untuk CNT (Peng et al. 2008) dan grafin (Zulkefli et al. 2016) (Jadual 1). Seperkara lagi, rintangan kekerasan dan haus untuk kedua-dua unsur aktif dan bahan elektrod juga akan menjadi semakin penting untuk prestasi dan kebolehharapan jangka panjang (Jang et al. 2008a). Terdapat juga kajian terbaru iaitu pengenalan struktur berlubang pada rusuk grafin yang digunakan di dalam aplikasi suis NEM (Rajah 5). Pengenalan struktur berlubang dijangka akan mengurangkan tekanan sisa biaksial dan kekukuhan rusuk grafin seterusnya menyumbang kepada pengurangan kesan-melentur rusuk grafin. Oleh kerana itu, struktur grafin berlubang dijangka akan meningkatkan prestasi peranti dan juga mengurangkan penggunaan kuasa operasi peranti. Pengenalan struktur grafin berlubang juga dijangka akan mengurangkan isu geseran statik peranti seterusnya meningkatkan kebolehharapan peranti kerana pengurangan di dalam kawasan-berkesan pada sentuhan antara-muka antara rasuk grafin berlubang dengan elektrod penarik.

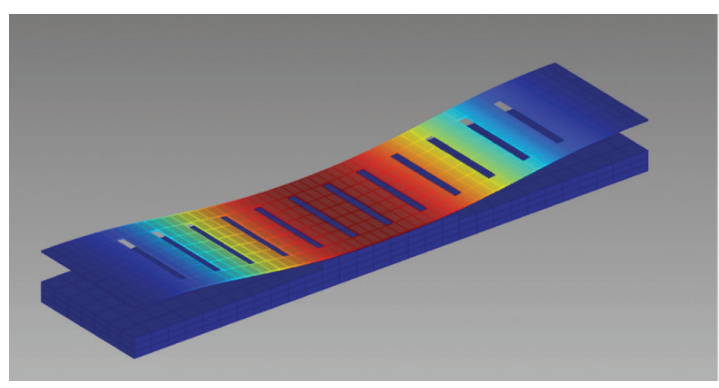

RAJAH 5. Suis NEM berstruktur hujung terkapit berasaskan rasuk grafin berlubang dalam keadaan mod-buka (Zulkefli et al. 2017)

Selain daripada itu, cabaran untuk mengintegrasikan suis NEM dan CMOS merupakan salah satu faktor yang penting dalam menghasilkan peranti berprestasi tinggi. Terdapat tiga keperluan utama suis NEM dalam peranti hibrid iaitu mengekalkan voltan penarikan yang rendah, memberi prestasi yang kukuh dan konsisten selepas banyak kitaran penarikan dan juga cukup kecil untuk beroperasi pada tahap yang tinggi. Di samping itu, ia juga perlu munasabah dalam memfabrikasikan peranti ini. Dalam banyak kes, keperluan ini meletakkan tuntutan yang berbeza daripada segi reka bentuk peranti contohnya, rusuk yang lebih patuh mengurangkan voltan tarik-dalam tetapi terdedah kepada isu geseran statik. Walau bagaimanapun, apabila proses fabrikasi dan bahan alternatif diperkenalkan, pelbagai reka bentuk peranti yang dapat meningkatkan prestasi peranti akan mula dijalankan. Jadual 3 meringkaskan beberapa cabaran yang berkaitan dengan proses mengintegrasikan suis NEM-CMOS.

\section{KEMAJUAN KINI DAN KEBOLEHHARAPAN PERANTI SUIS NEM}

Pelan Hala Tuju Teknologi Antarabangsa (ITRS) bagi semikonduktor ("International Technology Roadmap for Semiconductors - ITRS 2.0 Home Page" 2015) mengenal pasti teknologi baru yang berpotensi untuk mengekalkan hukum Moore. Antara teknologi yang disebut dalam pelan tersebut ialah pendekatan berasaskan CMOS seperti get pelbagai-peringkat dan get pelbagai-peranti ataupun keseluruhannya menggunakan pendekatan baru seperti peranti molekul dan suis NEM. Para penyelidik sebelum ini telah melaporkan suis elektrik, unsur ingatan, penderia, peranti logik dan geganti yang menggunakan teknologi 
JADUAL 3. Cabaran mengintegrasikan suis NEM dan CMOS

\begin{tabular}{|c|c|}
\hline Cabaran & Status terkini dan matlamat yang berbeza \\
\hline $\begin{array}{l}\text { Persamaan voltan } \\
\text { penarikan dengan peranti } \\
\text { CMOS semasa operasi } \\
\text { peranti yang selalunya } \\
\text { bawah } 1 \mathrm{~V}\end{array}$ & $\begin{array}{l}\text { Sesetengah peranti telah mencapai voltan penarikan sub-5 V manakala peranti lain selalunya memerlukan voltan } \\
\text { penarikan setinggi } 50 \mathrm{~V} \text {. Peranti dengan voltan penarikan sub- } 5 \mathrm{~V} \text { selalunya masih memerlukan denyutan yang } \\
\text { lebih tinggi untuk memecahkan daya lekatan dan membuka semula suis yang disebabkan pematuhan unsur } \\
\text { aktif yang keras. Pencapaian operasi meruap dengan penarikan sub- } 1 \mathrm{~V} \text { adalah sukar kerana unsur aktif tidak } \\
\text { kembali kepada tempat asal yang disebabkan oleh daya pengembalian elastik yang rendah }\end{array}$ \\
\hline $\begin{array}{l}\text { Penskalaan peranti dan } \\
\text { sentuhannya }\end{array}$ & $\begin{array}{l}\text { Daya pengembalian elastik pada suis NEM berstruktur julur berkurang lebih cepat berbanding dengan daya } \\
\text { kapilari atau daya van der Waals yang akan menyebabkan isu geseran statik. Di samping itu, ciri-ciri sentuhan } \\
\text { antara unsur aktif dan elektrod logam merosot dengan cepat apabila penskalaan peranti dijalankan. Sebagai } \\
\text { alternatif, elektrod logam yang disalut dengan selaput nipis contohnya karbon seperti berlian atau salutan nipis } \\
\text { boleh meningkatkan ciri-ciri sentuhan dan mengembangkan reka bentuk peranti yang sedia ada }\end{array}$ \\
\hline $\begin{array}{l}\text { Pengoperasian pada } \\
\text { persekitaran udara } \\
\text { ataupun memerlukan } \\
\text { pengkapsulan /vakum }\end{array}$ & $\begin{array}{l}\text { Majoriti suis NEM setakat ini menunjukkan pengoperasiannya dijalankan di dalam persekitaran vakum. Kadar } \\
\text { kemerosotan suis meningkat jika dioperasikan pada persekitaran udara(S. M. Kim et al. 2011) yang disebabkan } \\
\text { pengoksidaan, daya lekatan kapilari, pencemaran pada permukaan peranti yang memberi kesan kepada } \\
\text { interaksi antara unsur aktif dan elektrod sentuhan. Walau bagaimanapun, keperluan kepada pengkapsulan akan } \\
\text { meningkatkan keperluaan ruang dan proses fabrikasi peranti akan bertambah rumit }\end{array}$ \\
\hline Masa penarikan & $\begin{array}{l}\text { Pada masa kini, masa penarikan yang dilaporkan adalah dalam julat nano-saat atau lebih tinggi, manakala } \\
\text { peranti CMOS beroperasi dengan baik dalam julat gigahertz. Peranti yang lebih keras mempunyai frequensi } \\
\text { asli yang lebih tinggi, tetapi memerlukan voltan penarikan yang tinggi. Masa tarik-keluar boleh jadi jauh lebih } \\
\text { lama daripada masa tarik-dalam, dengan tempoh penetapan yang lama dan hujung rusuk yang melantun. Dalam } \\
\text { beberapa kes, sistem peranti boleh direka supaya masa tunda/penarikan tidak memberi kesan kepada kelajuan } \\
\text { keseluruhan peranti. Sebagai contoh, sel-sel SRAM NEM-CMOS telah direka supaya suis NEM yang perlahan } \\
\text { tidak menghadkan kelajuan keseluruhan litar }\end{array}$ \\
\hline $\begin{array}{l}\text { Proses meningkatkan } \\
\text { arus buka dan } \\
\text { mengurangkan rintangan } \\
\text { buka }\end{array}$ & $\begin{array}{l}\text { Setakat ini, peranti yang dilaporkan mempunyai rintangan buka (kebanyakannya dikuasai oleh rintangan sentuhan } \\
\mathrm{R}_{\mathrm{c}} \text { antara unsur aktif dan elektrod sentuhan)(Liu et al. 2014) yang terdiri daripada } \mathrm{k} \Omega \text { ke } \mathrm{G} \Omega \text {. Nilai } \mathrm{R}_{\mathrm{c}} \text { yang } \\
\text { rendah meningkatkan margin bunyi statik tetapi meningkatkan kecenderungan untuk peranti terbakar. Nilai } \mathrm{R}_{\mathrm{c}} \\
\text { yang tinggi pula mempunyai kesan yang sebaliknya. Arus buka setinggi } 10 \mu \mathrm{A} \text { telah dilaporkan walaupun tahap } \\
\text { nA adalah lebih biasa. Untuk voltan penarikan, arus buka adalah terikat kepada nilai } \mathrm{R}_{\mathrm{c}}\end{array}$ \\
\hline
\end{tabular}

suis NEM namun teknologi NEM adalah lebih digunakan untuk melengkapkan peranti CMOS seperti di dalam peranti hibrid dan bukannya untuk bersaing dengannya pada masa ini (Liao \& Koide 2011). Seperkara lagi, laporan ITRS ini juga menunjukkan perbandingan prestasi antara teknologi peranti NEM dengan beberapa jenis peranti transistor-kesan-medan-semikonduktor-logam-oksida (MOSFET) daripada segi lapan parameter telah ditunjukkan dalam Rajah 6. Berdasarkan laporan ini, walaupun suis NEM bersaing baik daripada segi kecekapan tenaga, keserasian bersama peranti CMOS dan suhu operasi tetapi kebolehharapan dan keperluan skala untuk suis NEM masih perlu dipertingkatkan.

Selain meningkatkan skala fabrikasi dan meramalkan tahap prestasi peranti, kita perlu menangani cabaran untuk meningkatkan kebolehharapan peranti dengan mengurangkan mod kegagalan yang biasa berlaku seperti geseran statik, haus dan lusuh serta kegagalan yang disebabkan oleh nyahcas elektrikal (Rajah 7). Dengan memeriksa beberapa suis NEM yang telah dinyatakan sebelum ini, kita dapati bahawa mod kegagalan menjadi kebiasaan apabila saiz peranti-peranti dikurangkan.

Geseran statik merupakan mod kegagalan yang lazim dalam kalangan para penyelidik industri semikonduktor dan geseran statik ini disebabkan oleh daya lekatan antara unsur aktif dan elektrod yang memastikan suis sentiasa dalam keadaan tertutup walaupun pincang elektrik telah dikurangkan sepenuhnya. Perkara ini diburukkan lagi jika berlaku pemanasan dan pengimpalan setempat pada unsur aktif serta elektrod. Di samping itu, bagi rintangan sentuhan pula, kemajuan dalam industri MEM boleh dijadikan sebagai panduan untuk menangani geseran statik dalam

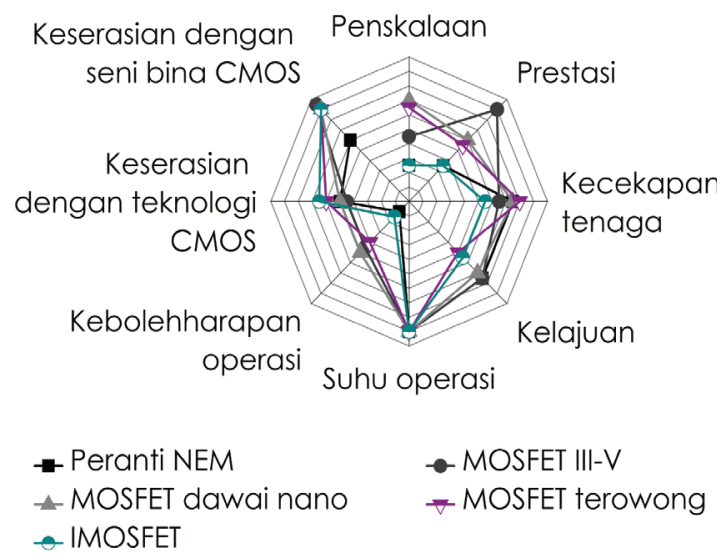

RAJAH 6. Laporan ITRS edisi 2009 menunjukkan perbandingan prestasi antara teknologi peranti NEM dengan beberapa jenis peranti MOSFET daripada segi lapan parameter 
suis berskala nano tetapi semua ini juga perlu membezakan antara magnitud van der Waals dengan daya elastik serta perbezaan kekasaran lapisan dengan dimensi unsur aktif.

Tambahan pula, bagi suis NEM meruap, geseran statik dianggap sebagai mod kegagalan (Rajah 7(a)). Sebagai contoh, 2-T dan 3-T suis NEM yang dibina berasaskan CNT serta grafin sebelum ini juga mengalami masalah yang sama iaitu geseran statik (Deshpande et al. 2006). Namun demikian, para penyelidik telah menunjukkan suis $2-\mathrm{T}$ dengan lapisan atom boleh mengurangkan daya lekatan (Dujardin et al. 2005) yang membolehkan puluhan kitaran balik. Kajian sebelum ini juga telah mengkaji kelebihan lapisan salutan karbon amorfus untuk meningkatkan prestasi suis NEM dan juga meningkatkan kitaran pensuisan, histeris yang kecil serta voltan tarik-dalam yang rendah. Penggunaan bahan-bahan elektrod alternatif juga boleh mengurangkan lekatan misalnya suis NEM CNT yang menggunakan elektrod karbon seperti berlian mengalami kurang lekatan jika dibandingkan dengan suis yang menggunakan elektrod emas (Ziegler et al. 2004). Oleh kerana itu, karbon seperti berlian memberikan lebih banyak pilihan dalam mereka bentuk geometri peranti.

Bagi situasi suis NEM tidak-meruap pula, geseran statik adalah diperlukan kerana situasi tersebut tidak memerlukan input voltan berterusan untuk memegang suis dalam keadaan tertutup. Walau bagaimanapun, untuk mengatasi geseran statik dan membalikkan keadaan suis tersebut, denyut voltan selalunya dikenakan kepada unsur aktif dan salah satu elektrod (Rueckes et al. 2000). Voltan ini selalunya lebih tinggi jika dibandingkan dengan voltan tarik-dalam. Pembaikan dalam kedua-dua bahan dan reka bentuk terutamanya pada kawasan sentuhan diperlukan untuk mengurangkan voltan ini.

Di samping itu, ablasi atau peleburan setempat yang berlaku pada unsur aktif atau sentuhan elektrod yang juga dikenali sebagai keadaan terbakar boleh menyebabkan kegagalan peranti. Unsur aktif akan membentuk kapasitor apabila suis dibuka. Seterusnya, apabila pincang voltan dinaikkan, caj dihasilkan di dalam kapasitor serta caj kapasitans parasit yang lain. Apabila suis ditutup, cas yang tersimpan menghilang dengan cepat melalui unsur aktif seterusnya menyebabkan kenaikan awal arus elektrik yang menjadikan magnitudnya lebih tinggi daripada keadaan sedia arus buka. Cara paling mudah untuk mengurangkan kegagalan terbakar adalah dengan mengurangkan jurang udara antara unsur aktif dan elektrod ataupun mengurangkan kekukuhan unsur aktif sekaligus dapat mengurangkan voltan tarik-dalam yang diperlukan dan jumlah tenaga yang disimpan di dalam sistem peranti. Namun demikian, semua ini juga mendatangkan kesan daripada segi peningkatan mod kegagalan geseran statik dan dengan itu meletakkan had ke atas geometri peranti atas beberapa pilihan bahan (Loh et al. 2012).

Selain itu, kadar nyahcas peranti sebahagian besarnya ditentukan oleh malar masa $R C$ dengan $R$ adalah rintangan sentuhan serta $C$ adalah kapasitans antara unsur aktif dan elektrod. Secara jelasnya, peningkatan rintangan sepatutnya akan memperlahankan kadar nyahcas seterusnya mengurangkan ketumpatan arus elektrik ke arah nilai keadaan-pegun. Sebagai contoh, penambahan salutan lapisan oksida ultranipis akan meningkatkan rintangan sentuhan dalam peranti seperti yang telah dikaji sebelum ini (Jang et al. 2008b). Semua ini telah menunjukkan bahawa peranti tersebut boleh beroperasi untuk ratusan kitaran sebelum ciri pensuisan mulai merosot disebabkan oleh lapisan oksida yang telah haus (Rajah 7(b)). Penggunaan media cecair penebat di sekeliling suis juga telah menunjukkan peningkatan dalam jangka hayat suis (dengan mengurangkan pelengkungan dan mengurangkan voltan tarik-dalam (Lee et al. 2009).

Mod kegagalan lesu dan patah (Rajah 7(c)) pula secara umumnya kurang berlaku dalam peranti berskala mikro dan nano tetapi kegagalan ini juga telah diperhatikan dalam kajian lepas (Davidson et al. 2011). Sebagai contoh, suis silikon karbida berjulur NEM telah mengalami kegagalan akibat patah atau gabungan patah dan lebur apabila beroperasi pada suhu yang tinggi serta selepas satu bilion kitaran operasi manakala struktur silikon tergantung juga (a)

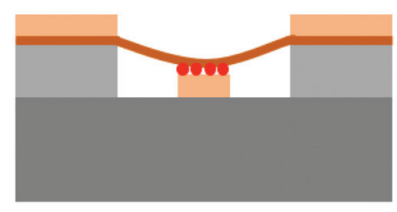

(c)

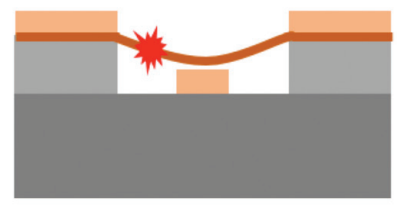

(b)

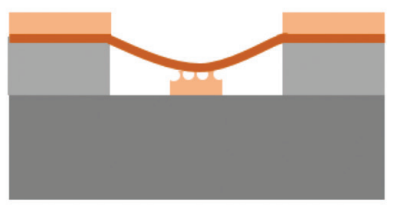

(d)

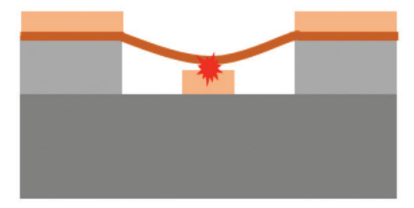

RAJAH 7. Gambarajah skema bagi jenis kegagalan suis NEM berstruktur hujung terkapit; (a) geseran statik berlaku antara unsur aktif dan elektrod, (b) lapisan elektrod menjadi haus, (c) kepatahan mekanikal berlaku pada unsur aktif dan (d) kerosakan pada unsur aktif dan elektrod disebabkan oleh nyahcas elektrik semasa proses tarik-dalam 
telah gagal selepas beberapa kitaran disebabkan patah (Han et al. 2010). Tekanan mekanikal yang dialami oleh unsur aktif secara umumnya adalah kurang daripada kekuatan patahnya, maka jika tiada kecacatan pada struktur unsur aktif, unsur aktif ini hanya mengalami terikan elastik contohnya regangan ikatan karbon-karbon dalam grafin dan bukannya patah.

\section{KESIMPULAN DAN PANDANGAN}

Prestasi cemerlang yang dicapai oleh sebilangan kecil suis NEM telah mendapat tempat dalam pelan halatuju ITRS sebagai pengganti berpotensi atau hibrid yang melengkapkan peranti CMOs konvensional kerana beberapa kelebihan seperti penggunaan komponen yang lebih kecil dalam peranti seterusnya mengurangkan pensuisan dinamik sebanyak $60 \%$ telah dilaporkan untuk hibrid get OR (Dadgour \& Banerjee 2007). Selain itu, hanya dua suis NEM digunakan untuk membuat get empat-terminal $X O R$, sedangkan get logik ini memerlukan sekurangkurangnya sepuluh transistor CMOS untuk membuatnya. Walaupun dekad yang mendatang akan memperlihatkan tumpuan berterusan dalam menunjukkan jenis-jenis fungsi yang baru bagi peranti suis NEM, penekanan yang lebih perlu diberikan kepada proses penskalaan dan persepaduan. Cabaran seperti pembaikan kebolehharapan dan membangunkan kaedah pertumbuhan struktur unsur aktif yang luas kawasannya serta tiada kecacatannya perlu dihadapi dalam merealisasikan peranti suis NEM yang berprestasi tinggi dan kos pembuatannya yang rendah.

Berdasarkan analisis kami yang menggunakan rangka kerja Kitaran Gemburan Gartner, teknologi dan penghasilan peranti suis NEM terletak di tiga lokasi iaitu lembah kekecewaan, cerun pencerahan dan dataran tinggi produktiviti seperti digambarkan di dalam Rajah 8. Sebagai contoh, teknologi suis NEM berasaskan silikon dijangka akan menghampiri lembah kekecewaan dalam Kitaran Gemburan Gartner kerana suis NEM berasaskan silikon ini tidak dapat memenuhi kriteria aplikasi peranti yang memerlukan voltan operasi di bawah 2 V. Di samping itu, pengenalan bahan baru iaitu bahan dua-dimensi seperti grafin yang lebih unggul daripada segi pencirian elektrikalnya serta mempunyai ketebalan bersaiz zarah turut menjadi faktor yang membawa suis NEM berasaskan silikon dan intan menghampiri ke arah jurang ilusi. Selain itu, teknologi NEM kemungkinan akan menuju ke cerun pencerahan daripada segi teknik pertumbuhan bahan unsur aktif sebagai contoh, kajian terdahulu (Cassell et al. 1999; Sun et al. 2016b) yang banyak berkisar kepada peningkatan prestasi proses pertumbuhan untuk mendapatkan unsur aktif yang luas kawasan pertumbuhannya. Daripada segi teknologi peranti hibrid MEM-CMOS pula kemungkinan berada di fasa dataran produktiviti dalam Kitar Gemburan Gartner jika dibandingkan dengan teknologi peranti hibrid NEM-CMOS kerana teknologi NEM perlu mengambil kira kesan fizik yang lebih kompleks. Teknologi NEM-CMOS boleh dikatakan berada di fasa cerun pencerahan dalam Kitaran Gemburan Gartner ("International Technology Roadmap for Semiconductors - ITRS 2.0 Home Page" 2015).

Pada masa ini, industri semikonduktor masih tidak dapat membina tatasusunan suis NEM secara besarbesaran dan industri semikonduktor juga masih tidak dapat menjalankan kajian berparameter yang diperlukan untuk mengoptimumkan sepenuhnya reka bentuk peranti seperti mengenal pasti geometri dan bahan terbaik untuk mengimbangi kesan pematuhan mekanikal serta rintangan sentuhan. Model analisis dan pengiraan yang boleh meramal tindak balas fizik yang pelbagai dan dinamik untuk peranti pula akan menjadi semakin penting dengan tindak balas bagi mekanikal, elektrikal dan haba digandingkan semuanya bersama-sama. Apabila peranti terus dikecilkan, model ini perlu mengambil kira kesan kuantum seperti kesan Casimir yang dapat mempengaruhi voltan tarik-dalam dan operasi peranti serta teknik pemodelan juga diperlukan untuk meningkatkan hasil daripada pelbagai teknik fabrikasi nano.

Di samping itu, penggunaan pertama suis berasaskan NEM kemungkinan akan berada dalam sistem kuasa ultrarendah atau sistem bersuhu tinggi disebabkan oleh

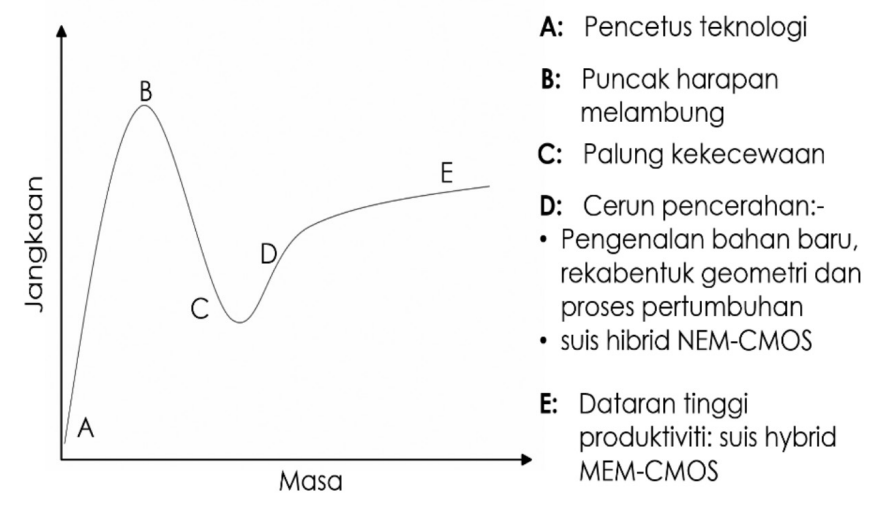

RAJAH 8. Kitaran Gemburan Gartner yang menunjukkan lima fasa penting untuk teknologi suis NEM 
ciri penskalaan dan kelajuan pensuisan untuk kedua-dua sistem ini menjadi kurang kritikal manakala pengenalan integrasi NEM-CMOS untuk seni bina pengkomputeran elektromekanikal akan melibatkan cabaran yang perlu diatasi seperti menyamakan voltan operasi dan kebimbangan dalam proses pembungkusan. Apabila kaedah fabrikasi dan seni bina peranti terus berkembang, prestasi suis NEM akan mula menghampiri kepada prestasi yang dijangka oleh kaedah pemodelan dan simulasi. Setelah semua ini dicapai, seni bina peranti NEM dan sistem hibrid yang lain mungkin akan mengatasi peranti CMOS daripada segi kelajuan pensuisan sambil menawarkan penggunaan kuasa yang rendah. Akhirnya, apabila suis NEM terus bersaing secara langsung dengan transistor CMOS daripada segi prestasi, penggunaan seni bina struktur unsur aktif tunggal berpotensi untuk membantu peranti beroperasi ke arah prestasi yang paling tinggi walaupun semua ini juga akan melibatkan cabaran teknologi dan sains yang perlu diatasi.

\section{PENGHARGAAN}

Penulis ingin merakamkan jutaan terima kasih dan setinggitinggi penghargaan atas sokongan sumber kewangan yang telah diberikan oleh Kementerian Pengajian Tinggi Malaysia (KPT) melalui dana LRGS/2015/UKM-UKM/ NANOMITE/04/01.

\section{RUJUKAN}

Abele, N., Fritschi, R., Boucart, K., Casset, F., Ancey, P. \& Ionescu, A.M. 2005. Suspended-Gate MOSFET: Bringing new MEMS functionality into solid-state MOS transistor. IEEE International Electron Devices Meeting pp. 479-481. doi:10.1109/IEDM.2005.1609384.

Amaratunga, G.A.J. 2002. A dawn for carbon electronics?. Science 297(5587): 1657-1658. doi:10.1126/science.1075868.

Avouris, P., Chen, Z. \& Perebeinos, V. 2007. Carbon-based electronics. Nature Nanotechnology 2(10): 605-615. doi:10.1038/nnano.2007.300.

Balandin, A.A., Ghosh, S., Bao, W., Calizo, I., Teweldebrhan, D., Miao, F. \& Lau, C.N. 2008. Superior thermal conductivity of single-layer graphene. Nano Letters 8(3): 902-907.

Bolotin, K.I., Sikes, K.J., Jiang, Z., Klima, M., Fudenberg, G., Hone, J., Kim, P. \& Stormer, H.L. 2008. Ultrahigh electron mobility in suspended graphene. Solid State Communications 146(9): 351-355. doi:10.1016/j.ssc.2008.02.024.

Cassell, A.M., Raymakers, J.A., Kong, J. \& Dai, H. 1999. Large scale CVD synthesis of single-walled carbon nanotubes. The Journal of Physical Chemistry B 103(31): 6484-6492. doi:10.1021/jp990957s.

Cimalla, V., Pezoldt, J. \& Ambacher, O. 2007. Group III nitride and $\mathrm{SiC}$ based MEMS and NEMS: Materials properties, technology and applications. Journal of Physics D: Applied Physics 40(20): 6386. doi:10.1088/0022-3727/40/20/S19.

Cui, Y. \& Lieber, C.M. 2001. Functional nanoscale electronic devices assembled using silicon nanowire building blocks. Science 291(5505): 851-853. doi:10.1126/ science.291.5505.851.

Dadgour, H.F. \& Banerjee, K. 2009. Hybrid NEMS-CMOS integrated circuits: A novel strategy for energy-efficient designs. IET Computers \& Digital Techniques 3(6): 593-608. doi:10.1049/iet-cdt.2008.0148.

Dadgour, H.F. \& Banerjee, K. 2007. Design and analysis of hybrid NEMS-CMOS circuits for ultra low-power applications. In Proceedings of the 44th Annual Design Automation Conference. pp. 306-311. ACM. doi:10.1109/ DAC.2007.375177.

Dadgour, H., Hussain, M.M. \& Banerjee, K. 2010. A new paradigm in the design of energy-efficient digital circuits using laterally-actuated double-gate NEMS. Proceedings of the 16th ACM/IEEE International Symposium on Low Power Electronics and Design. pp. 7-12. ACM.. doi:10.1145/1840845.1840848.

Dadgour, H., Cassell, A.M. \& Banerjee, K. 2008. Scaling and variability analysis of CNT-based NEMS devices and circuits with implications for process design. IEEE International Electron Devices Meeting, 2008. IEDM 2008. pp. 1-4. doi:10.1109/IEDM.2008.4796742.

Davidson, B.D., Seghete, D., George, S.M. \& Bright, V.M. 2011. ALD Tungsten NEMS switches and tunneling devices. Sensors and Actuators A: Physical 166(2): 269-276. doi:10.1016/j.sna.2009.07.022.

Dekker, C., Tans, S.J., Devoret, M.H., Dai, H., Smalley, R.E., Thess, A. \& Georliga, L.J. 1997. Individual single-wall carbon nanotubes as quantum wires. Nature 386(6624): 474-477. doi:10.1038/386474a0.

Deshpande, V.V., Chiu, H.Y., Postma, H.C., Miko, C., Forro, L. \& Bockrath, M. 2006. Carbon nanotube linear bearing nanoswitches. Nano Letters 6(6): 1092-1095. doi:10.1021/ n1052513f.

Dujardin, E., Derycke, V., Goffman, M.F., Lefevre, R. \& Bourgoin, J.P. 2005. Self-assembled switches based on electroactuated multiwalled nanotubes. Applied Physics Letters 87(19): 193107.doi:10.1063/1.2126805.

Eichler, A., Moser, J., Chaste, J., Zdrojek, M. \& Bachtold, A. 2011. Nonlinear damping in mechanical resonators made from carbon nanotubes and graphene. Nature Nanotechnology 6(6): 339-342. doi:10.1038/nnano.2011.71.

Feng, X.L., Matheny, M.H., Zorman, C., Mehregany, A.M. \& Roukes, M.L. 2010. Low voltage nanoelectromechanical switches based on silicon carbide nanowires. Nano Letters 10(8): 2891-2896. doi:10.1021/nl1009734.

Frank, I.W., Tanenbaum, D.M., Van der Zande, A.M. \& McEuen, P.L. 2007. Mechanical properties of suspended graphene sheets. Journal of Vacuum Science \& Technology B: Microelectronics and Nanometer Structures Processing, Measurement, and Phenomena 25(6): 2558-2561. doi:10.1116/1.2789446.

Franklin, A.D. \& Chen, Z. 2010. Length scaling of carbon nanotube transistors. Nature Nanotechnology 5(12): 858-862. doi:10.1038/nnano.2010.220.

Geim, A.K. \& Novoselov, K.S. 2007. The rise of graphene. Nature Materials 6(3): 183-191. doi:10.1038/nmat1849.

Han, J.W., Ahn, J.H., Kim, M.W., Lee, J.O., Yoon, J.B. \& Choi, Y.K. 2010. Nanowire mechanical switch with a built-in diode. Small 6(11): 1197-1200. doi:10.1002/smll.201000170.

Hopcroft, M.A., Nix, W.D. \& Kenny, T.W.2010. What is the Young's modulus of silicon? Journal of Microelectromechanical Systems 19(2): 229-238.doi:10.1109/JMEMS.2009.2039697.

International Technology Roadmap for Semiconductors - ITRS 2.0 Home Page. 2015. http://www.itrs2.net/.

Jang, J.E., Cha, S.N., Choi, Y.J., Kang, D.J., Butler, T.P., Hasko, D.G., Jung, J.E., Kim, J.M. \& Amaratunga, G.A. 2008. 
Nanoscale memory cell based on a nanoelectromechanical switched capacitor. Nature Nanotechnology 3(1): 26-30. doi:10.1038/nnano.2007.417.

Jang, J.E., Cha, S.N., Choi, Y., Amaratunga, G.A., Kang, D.J., Hasko, D.G., Jung, J.E. \& Kim, J.M. 2005. Nanoelectromechanical switches with vertically aligned carbon nanotubes. Applied Physics Letters 87(16): 163114. doi:10.1063/1.2077858.

Jang, W.W., Lee, J.O., Yoon, J.B., Kim, M.S., Lee, J.M., Kim, S.M., Cho, K.H., Kim, D.W., Park, D. \& Lee, W.S. 2008 a. Fabrication and characterization of a nanoelectromechanical switch with 15-nm-thick suspension air gap. Applied Physics Letters 92(10): 103110. doi:10.1063/1.2892659.

Jang, W.W., Yoon, J.B., Kim, M.S., Lee, J.M., Kim, S.M., Yoon, E.J., Cho, K.H. \& Park, D. 2008b. NEMS switch with 30nmthick beam and 20nm-thick air-gap for high density nonvolatile memory applications. Solid-State Electronics 52(10): 1578-1583. doi:10.1016/j.sse.2008.06.026.

Jensen, K., Kim, K. \& Zettl, A. 2008. An atomic-resolution nanomechanical mass sensor. Nature Nanotechnology 3(9): 533-537. doi:10.1038/nnano.2008.200.

Kim, J.H., Chen, Z.C., Kwon, S. \& Xiang, J. 2014. Threeterminal nanoelectromechanical field effect transistor with abrupt subthreshold slope. Nano Letters 14(3): 1687-1691. doi: $10.1021 / \mathrm{nl} 5006355$.

Kim, P. \& Lieberl, C.M. 1999. Nanotube nanotweezers. Science 286(5447): 2148-2150. doi:10.1126/science.286.5447.2148.

Kim, S.M., Song, E.B., Lee, S., Seo, S., Seo, D.H., Hwang, Y., Candler, R. \& Wang, K.L. 2011. Suspended few-layer graphene beam electromechanical switch with abrupt on-off characteristics and minimal leakage current. Applied Physics Letters 99(2): 023103. doi:10.1063/1.3610571.

Krishnan, A., Dujardin, E., Ebbesen, T.W., Yianilos, P.N. \& Treacy, M.M.J. 1998. Young's modulus of single-walled nanotubes. Physical Review B 58(20): 14013. doi:10.1103/ PhysRevB.58.14013.

Lee, J.O., Kim, M.W., Ko, S.D., Kang, H.O., Bae, W.H., Kang, M.H., Kim, K., Yoo, D.E. \& Yoon, J.B. 2009. 3-terminal nanoelectromechanical switching device in insulating liquid media for low voltage operation and reliability improvement. 2009 IEEE International Electron Devices Meeting (IEDM). pp. 1-4. doi:10.1109/IEDM.2009.5424380.

Lee, J.O., Song, Y.H., Kim, M.W., Kang, M.H., Oh, J.S., Yang, H.H. \& Yoon, J.B. 2013. A sub-1-volt nanoelectromechanical switching device. Nature Nanotechnology 8(1): 36-40. doi:10.1038/nnano.2012.208.

Lee, T.H., Bhunia, S. \& Mehregany, M. 2010. Electromechanical computing at $500^{\circ} \mathrm{C}$ with silicon carbide. Science $329(5997)$ : 1316-1318. doi:10.1126/science.1192511.

Lee, S.W., Lee, D.S., Morjan, R.E., Jhang, S.H., Sveningsson, M., Nerushev, O.A., Park, Y.W. \& Campbell, E.E.B. 2004. A three-terminal carbon nanorelay. Nano Letters 4(10): 2027 2030. doi: $10.1021 / \mathrm{n} 1049053 \mathrm{v}$.

Li, P., Jing, G., Zhang, B., Sando, S. \& Cui, T. 2014. Singlecrystalline monolayer and multilayer graphene nano switches. Applied Physics Letters 104(11): 113110. doi:10.1063/1.4868869.

Li, S., Yu, Z., Yen, S.F., Tang, W.C. \& Burke, P.J. 2004. Carbon nanotube transistor operation at $2.6 \mathrm{GHz}$. Nano Letters 4(4): 753-756. doi:10.1021/n10498740.

Liao, M. \& Koide, Y. 2011. Carbon-based materials: Growth, properties, MEMS/NEMS technologies, and MEM/NEM switches. Critical Reviews in Solid State and Materials Sciences 36(2): 66-101. doi:10.1080/10408436.2011.572748.

Liu, X., Suk, J.W., Boddeti, N.G., Cantley, L., Wang, L., Gray, J.M., Hall, H.J., Bright, V.M., Rogers, C.T., Dunn, M.L. \& Ruoff, R.S. 2014. Large arrays and properties of 3-terminal graphene nanoelectromechanical switches. Advanced Materials 26(10): 1571-1576. doi:10.1002/adma.201304949.

Loh, O.Y. \& Espinosa, H.D. 2012. Nanoelectromechanical contact switches. Nature Nanotechnology 7(5): 283-295. doi:10.1038/nnano.2012.40.

Loh, O., Wei, X., Sullivan, J., Ocola, L.E., Divan, R. \& Espinosa, H.D. 2012. Carbon-carbon contacts for robust nanoelectromechanical switches. Advanced Materials 24(18): 2463-2468. doi:10.1002/adma.201104889.

Loh, O., Wei, X., Ke, C., Sullivan, J. \& Espinosa, H.D. 2011. Robust carbon-nanotube-based nano-electromechanical devices: Understanding and eliminating prevalent failure modes using alternative electrode materials. Small 7(1): 7986. doi:10.1002/smll.201001166.

Milaninia, K.M., Baldo, M.A., Reina, A. \& Kong, J. 2009. All graphene electromechanical switch fabricated by chemical vapor deposition. Applied Physics Letters 95(18): 183105. doi:10.1063/1.3259415.

Moldovan, C.F., Vitale, W.A., Sharma, P., Bernard, L.S. \& Ionescu, A.M. 2015. Fabrication process and characterization of suspended graphene membranes for RF NEMS capacitive switches. Microelectronic Engineering 145: 5-8. doi:10.1016/j.mee.2015.01.032.

Moore, G.E. 1965. Cramming more components onto integrated circuits. Electronics 38(8): 82-85. doi:10.1109/ JPROC.1998.658762.

Murali, R., Brenner, K., Yang, Y., Beck, T. \& Meindl, J.D. 2009. Resistivity of graphene nanoribbon interconnects. IEEE Electron Device Letters 30: 611-613. doi:10.1109/ LED.2009.2020182.

Novoselov, K.S., Geim, A.K., Morozov, S.V., Jiang, D., Zhang, Y., Dubonos, S.V., Grigorieva, I.V. \& Firsov, A.A. 2004. Electric field effect in atomically thin carbon films. Science 306(5696): 666-669. doi:10.1126/science.1102896.

Peng, B., Locascio, M., Zapol, P., Li, S., Mielke, S.L., Schatz, G.C. \& Espinosa, H.D. 2008. Measurements of near-ultimate strength for multiwalled carbon nanotubes and irradiationinduced crosslinking improvements. Nature Nanotechnology 3(10): 626-631. doi:10.1038/nnano.2008.211.

Peschot, A., Qian, C. \& Liu, T.J.K. 2015. Nanoelectromechanical switches for low-power digital computing. Micromachines 6(8): 1046-1065. doi:10.3390/mi6081046.

Qian, Y., Lou, L., Julius Tsai, M. \& Lee, C. 2012. A dual-siliconnanowires based U-shape nanoelectromechanical switch with low pull-in voltage. Applied Physics Letters 100 113102: 2010-2013. doi:10.1063/1.3693382.

Rueckes, T., Kim, K., Joselevich, E., Tseng, G.Y., Cheung, C.L. \& Lieber, C.M. 2000. Carbon nanotube-based nonvolatile random access memory for molecular computing. Science 289(5476): 9497. doi:10.1126/science.289.5476.94.

Schwierz, F. 2010. Graphene transistors. Nature Nanotech 5(7): 487-496. doi:10.1038/nnano.2010.89.

Shi, Z., Lu, H., Zhang, L., Yang, R., Wang, Y., Liu, D., Guo, H., Shi, D., Gao, H., Wang, E. \& Zhang, G. 2012. Studies of graphene-based nanoelectromechanical switches. Nano Research 5(2): 82-87. doi:10.1007/s12274-011-0187-9.

Siow, K.S. 2017. Graphite exfoliation to commercialize graphene technology. Sains Malaysiana 46(7): 1047-1059. 
Stampfer, C., Jungen, A., Linderman, R., Obergfell, D., Roth, S. \& Hierold, C. 2006. Nano-electromechanical displacement sensing based on single-walled carbon nanotubes. Nano Letters 6(7): 1449-1453. doi:10.1021/n10606527.

Standley, B., Bao, W., Zhang, H., Bruck, J., Lau, C.N. \& Bockrath, M. 2008. Graphene-based atomic-scale switches. Nano Letters 8(10): 3345-3449. doi:10.1021/n1801774a.

Sun, J., Muruganathan, M., Kanetake, N. \& Mizuta, H. 2016 a. Locally-actuated graphene-based nano-electro-mechanical switch. Micromachines 7(124): 1-6. doi:10.3390/mi7070124.

Sun, J., Schmidt, M.E., Muruganathan, M., Chong, H.M. \& Mizuta, H. 2016b. Large-scale nanoelectromechanical switches based on directly deposited nanocrystalline graphene on insulating substrates. Nanoscale 8(12): 6659-6665. doi:10.1039/C6NR00253F.

Sun, J., Wang, W., Muruganathan, M. \& Mizuta, H. 2014. Low pull-in voltage graphene electromechanical switch fabricated with a polymer sacrificial spacer. Applied Physics Letters 105(33103): 2-5. doi:10.1063/1.4891055.

Theis, T.N. \& Solomon, P.M. 2012. It's time to reinvent the transistor! Science 327(5973): 1600-1601. doi:10.1126/ science.1187597.

Wei, D., Liu, Y., Zhang, H., Huang, L., Wu, B., Chen, J. \& Yu, G. 2009. Scalable synthesis of few-layer graphene ribbons with controlled morphologies by a template method and their applications in nanoelectromechanical switches. JACS Articles 131: 11147-11154. doi:10.1021/ja903092k.

Yavari, F., Kritzinger, C., Gaire, C., Song, L., Gulapalli, H., Borca-Tasciuc, T., Ajayan, P.M. \& Koratkar, N. 2010. Tunable bandgap in graphene by the controlled adsorption of water molecules. Small 6(22): 2535-2538. doi:10.1002/ smll.201001384.
Ziegler, K.J., Lyons, D.M., Holmes, J.D., Erts, D., Polyakov, B., Olin, H., Svensson, K. \& Olsson, E. 2004. Bistable nanoelectromechanical devices. Applied Physics Letters 84(20): 4074-4076. doi:10.1063/1.1751622.

Zulkefli, M.A., Mohamed, M.A., Siow, K.S., Yeop Majlis, B., Kulothungan, J., Muruganathan, M. \& Mizuta, H. 2017. Three-dimensional finite element method simulation of perforated graphene nano-electro-mechanical (NEM) switches. Micromachines 8(8): 236. doi:10.3390/mi8080236.

Zulkefli, M.A., Mohamed, M.A., Siow, K.S. \& Majlis, B.Y. 2016. Optimization of beam length and air gap of suspended graphene NEMS switch for low pull-in voltage application. 2016 IEEE International Conference on Semiconductor Electronics (ICSE) 1: 29-32. doi:10.1109/ SMELEC.2016.7573583.

Institute of Microengineering and Nanoelectronics (IMEN)

Universiti Kebangsaan Malaysia

43600 UKM Bangi, Selangor Darul Ehsan

Malaysia

*Pengarang untuk surat-menyurat; email: ambri@ukm.edu.my

Diserahkan: 3 Julai 2017

Diterima: 23 Oktober 2017 